\title{
Techniques of Developing Fine Motor Skill Through Collage Art Activities Among Children Aged between 5- 6 Years in PAUD Mataram City
}

\author{
I Made Suwasa Astawa ${ }^{1}$ and Ni Wayan Purni Astuti ${ }^{2}$ \\ ${ }^{1}$ Early Childhood Department, University of Mataram, Mataram, Indonesia, astawa.fkip@ gmail.com \\ ${ }^{2}$ Early Childhood Department, University of Mataram, Mataram, Indonesia
}

\begin{abstract}
Early childhood has potential that still needs to be developed, among these potentials is the development of fine motor, one way to develop fine motor is through art collage activities, fine motor is a movement that involves the eye to hand. Art collage is an educational activity that can be used to develop fine motor skills of children aged 5-6 years, in early childhood education in Mataram City. -6 years in PAUD Kota Mataram. To achieve these goals using this type of research development, children's data analysis is given the opportunity to play while learning through collage art activities. Research Results Development I average value of 52.4\% in Development II the average value of children $65.4 \%$ an increase of $13 \%$ from Development I to Development II and Development III the average value of children $77.49 \%$ an increase 25 , 09\% from Development I to Development III based on the data obtained, it can be concluded, that collage activities with eggshells can improve fine motor skills of children aged 5-6 years in PAUD Kota Mataram.
\end{abstract}

Keywords: Fine motor, collage art, eggshell.

\section{BACKGROUND}

The world of children is the beginning of the development of creativity, imagination and all the potential they have. Learning activities for children which are supported by various facilities such as teaching aids, media and various learning resources will be beneficial for accelerating the achievement of development results through learning. Early childhood education is the most basic education for the formation of human resources in the future, the quality of early childhood education will determine the quality of human resources in a country. The better the quality of education of children in their early age, the more quality is also the resources that will be produced by the next generation. This is because early childhood is a place for learning and human habituation in facing life's challenges in order to be able to survive in a variety of situations

Law Number 20 Year 2003 concerning the National Education System article 1 paragraph 14 states that: "Early childhood education is a coaching effort that is shown to children from birth until the age of six carried out through the provision of educational stimuli to assist physical growth and development. and spiritual children to have readiness to enter further education, (Regulation of the Minister of National Education of the Republic of Indonesia Number 58 of 2009 concerning Early Childhood Education Standards).

For children to play is a fun learning tool through play, children's fine motor movements will always be trained with stimulation. Fine motor skills are the ability to use small muscles such as fingers, arms that often require careful eye and hand coordination, for example such as writing and drawing by hand, Suyanto, S. (2005: 7). Besides fine motor skills are important because it has a function as self-help skills such as eating, bathing, dressing, social assistance skills such as helping with homework or school, Sumantri, MS. (2005: 23). Playing skills such as building blocks into a building or composing puzzles into whole shapes, and school skills such as drawing or painting. In well-coordinated motor skills, small muscles play a large role, Hurlock (1997: 154-163).

Various types of early childhood activities such as writing, cutting, tracing, coloring, folding, drawing lines and can also be through an art collage approach. The development of collage art aims to develop the fine motor skills of students in working hands, Abdulhak (2007: 14). One of them is the learning of the fine arts in collage activities using eggshells. The fine motor characteristics of a child that are compatible with collage art activities are: (1) sticking to small pieces consisting of; (a) sticks according to a predetermined pattern, (b) The child is able to use and move the fingers of the hand to make the shape of the picture that has been determined at the time of a simple pattern collage, (2) Exploring (a) The child is able to select pieces in accordance with the size of the image, (b) using collage stages according to their age level, (3) expressing themselves through collage movements in detail consisting of; (a) The child is able to stick without 
covering, (b) coordinate the eyes and hands to make complicated movements, (c) complete the collage in an orderly and neat manner. SyakirMuharrar et al. (2005: 16).

This collage art activity involves elements of muscles, nerves, brain, and fingers. Children are trained to pin, glue so as to increase the flexibility of the child's fingers. This is where the elements will be coordinated if done intensively. Collage is considered to be a place to hone creativity, be able to develop ideas, channel emotions, foster an interest in art, as well as optimize the fine motor skills of preschool children.

Seeing the problems that occur especially in children aged 5-6 years, based on observations in Mataram City PAUD shows that some children still have low fine motor skills, especially in prewriting activities

\section{RESEARCH METHODS}

To obtain data in this study using the type of research development through observation, interviews and documentation. Data analysis uses a comparison between the observations and documentation of pre (before) as many as 10 PAUD institutions in the City of Mataram activities and the results of post (after) activities. After the data in the research is collected, it will then be analyzed using the following formula:

Formula :

$$
\mathrm{NA}=\frac{\mathrm{SA}}{\mathrm{SMi}} \times 100 \%
$$

Information :

$\mathrm{NA}=$ Final Value

$\mathrm{SA}=$ Score Obtained by Children

$\mathrm{SMi}=$ Ideal maximum score

(Nurkencana et al. 1990: 14)

Value Conversion:

Score 1: Very less (achievement indicators that appear very less)

Score 2: Poor (achievement indicators that appear are still lacking)

Score 3: Sufficient (achievement of the indicators that appear quite good)

Score 4: Good (achievement indicators that appear are good)

\section{RESEARCH RESULTS AND DISCUSSION}

After conducting research, researchers obtain observations during the study and observational data before the activity, during the activity and after the research activity. Based on the data obtained from the activity, the development before the activity is obtained results that show that the fine motor development of children is still low. The data obtained on the fine motor development of children 5-6 years in the city of Mataram in the pre-activity stage the number of children who have not been able to do collages with a predetermined image form, using the adhesive tool carefully and carefully, forming a collage with an undetermined form. Make a background and have a name with an eggshell and move your fingers to make complicated movements and eye and hand coordination, pretty much in the pre-activity stage.

Development I average value of $52.4 \%$ in Development II the average value of children $65.4 \%$ there was a $13 \%$ increase from development I to Development II.Development III, the average value of children is $77.49 \%$, an increase of $25.09 \%$ from before the activity until after the activity can be seen in the table as follows:

Outcomes of Improvement of Fine Motoric Capabilities of Children 5-6 Years at Collage Development Activities I, II, and III.

Table 1. The outcomes of improvement

\begin{tabular}{|l|l|l|l|l|}
\hline \multirow{2}{*}{ No. } & \multirow{2}{*}{ Name } & \multicolumn{3}{|c|}{ Comparison } \\
\cline { 3 - 5 } & & $\begin{array}{c}\text { Develovment } \\
\text { I }\end{array}$ & $\begin{array}{c}\text { Develovment } \\
\text { II }\end{array}$ & $\begin{array}{c}\text { Develovment } \\
\text { III }\end{array}$ \\
\hline 1 & $\mathrm{~A}$ & $55 \%$ & $67 \%$ & $78,84 \%$ \\
\hline 2 & $\mathrm{~B}$ & $50 \%$ & $67,5 \%$ & $76,92 \%$ \\
\hline 3 & $\mathrm{C}$ & $57 \%$ & $69,2 \%$ & $80,76 \%$ \\
\hline 4 & $\mathrm{D}$ & $57,5 \%$ & $67,5 \%$ & $78,84 \%$ \\
\hline 5 & $\mathrm{E}$ & $50 \%$ & $62,5 \%$ & $75 \%$ \\
\hline 6 & $\mathrm{~F}$ & $50 \%$ & $66,25 \%$ & $76,92 \%$ \\
\hline 7 & $\mathrm{G}$ & $55 \%$ & $67,5 \%$ & $78,84 \%$ \\
\hline 8 & $\mathrm{H}$ & $50 \%$ & $63,75 \%$ & $76,92 \%$ \\
\hline 9 & $\mathrm{I}$ & $50 \%$ & $57,5 \%$ & $75 \%$ \\
\hline 10 & $\mathrm{~J}$ & $50 \%$ & $66,25 \%$ & $76,92 \%$ \\
\hline & Total & $\mathbf{5 2 , 4 \%}$ & $\mathbf{6 5 , 4} \%$ & $\mathbf{7 7 , 4 9} \%$ \\
\hline
\end{tabular}

In Development I, II, III collage with a predetermined image shape, use a careful and careful adhesive tool, form an image with an undetermined shape, make a background and write your own name with an eggshell and move your fingers to make a move complicated and eye and hand coordination, has begun to increase compared to the Development Phase I. The criteria obtained at Development Phase II reached a value of $65.4 \%$ with quite good criteria, which are expected to be carried out the next development stage, namely Development III. can be seen in the histogram as follows: Outcomes of Improvement of Fine Motor Ability in Children Aged 5-6 Years in Collage Development Activities I, II, and III.

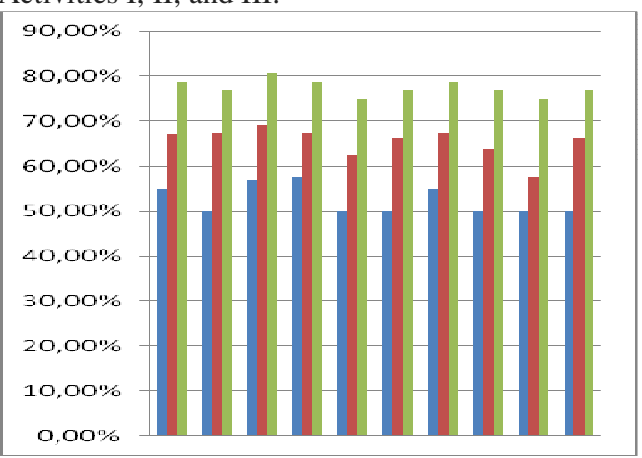

Figure 1. The outcomes of improvement 
The improvements made by researchers include inviting children to be more focused so that children are able to do collage technique movements as well as the Development I stage for the beginning before the activity is carried out, the teacher invites children to sit together and do questions and answers about the theme on the day after the question and answer, The teacher then explains and shows the activities to be carried out namely collage using egg shells.

In the Development Phase III the number of children who are able to carry out activities in the development of fine motor skills includes collage activities with a predetermined image form, using an adhesive tool carefully and carefully, forming images with undetermined shapes, making backgrounds and writing their own names with the eggshell and moving the fingers to make complicated movements and eye and hand coordination, again experienced an increase compared to when the activity was able to reach a performance indicator that is a value of $77.49 \%$ with good criteria.

\section{CONCLUSIONS AND SUGGESTIONS}

Based on the conclusions of the study entitled "Techniques to develop fine motor skills through collage activities with egg shells of children aged 5-6 years in the City of Mataram, it is concluded:

1. In Development I, the average percentage reached $52.4 \%$ with an average value of 27.4 at the time of kelase activities in a predetermined form. Very poorly developed motor children need stimulation to reach the target of the researcher.

2. In Development II, the average percentage reached $65.4 \%$ with an average value of 34.4 , an increase of $13 \%$ from before the activity to the time of the activity, collage in the form of images that have been determined and able to create images that have not been determined according to collage techniques.

3. In Development III, the child is able to stick to the picture appropriately, be able to use the adhesive material carefully and use the adhesive material carefully and carefully and regularly on the media that has been provided to be able to stick without covering the image, able to produce collage art with Forms in accordance with collage techniques in the child's fine motor skills with an average percentage of $77.49 \%$ which can be rounded to $80 \%$.

The results of research and discussion it can be concluded that the Development of Fine Motor Skills is an average percentage of $52.4 \%$ and in Development II an average percentage of $65.4 \%$ and Development III an average percentage of $77.49 \%$. So it can be seen that collage activities can be used as play activities while learning which can improve fine motor skills at the age of 5-6 years. Based on the conclusions obtained from the results of the study it is suggested as follows:

1. Teachers in developing fine motor skills children should have creativity to multiply activities that can develop fine motor skills for example in addition to the art of collage children can be invited to morance, cut, and so on.

2. PAUD Institution, as a important policy in order to realize activities that can improve children's fine motor skills, equipment, tools, materials should always be provided for the learning process in improving children's fine motor skills.

\section{REFERENCES}

[1] Abdulhak, 2007.Growth and Development of Kindergarten Children, Jakarta: PT. Grasindo.

[2] Ministry of Education. 2003. Model Motor Development for Preschoolers. Jakarta: Directorate of Community Sports.

[3] Gordon and Brone, Moeslichatoen.2004. Teaching Methods in Kindergarten. Jakarta: RinekaCipta.

[4] Hurlock, B Elizabeth. 1997. Child Volume Development 1. Jakarta: Erlangga.

[5] Nurkencana. 1990. Early Childhood Development and Development Kindergarten Guidelines for Parents and Teachers. PPS PPS UNJ Program. Jakarta

[6] Regulation of the Minister of National Education of the Republic of Indonesia No. 58 of 2009, concerning Early Childhood Education Standards: Jakarta.

[7] Puskur, BelibangDepdiknas, Sumantri 2005.Models of Preschool Children's Motor Development.Jakarta: Directorate of Community Sports.

[8] Sujiono, YulianiNuraini and SujioniBambang. 2010. Creative Play Based on Multiple Intelligences. Jakarta: PT. Index.

[9] Sumantri, MS. 2005. Basic Concepts of Early Childhood Education.Jakarta: Director of Higher Education Education and Serenity.

[10]Suyanto, S. 2005. Basic Concepts of Early Childhood Education. Jakarta: Director of Higher Education Education and Personnel Development.

[11] SyakirMuharrar\&SitiVerayanti, 2005.Simple Mozage Montage Collage. Jakarta. 